\title{
¿Y vivieron felices y comieron perdices?: la mujer casada en los cuentos populares de los oasis del Valle Nuevo (Egipto)
}

\author{
Celeste Seoane Miguez \\ Escola Oficial de Idiomas da Coruña \\ celesteseoane@gmail.com
}

\section{RESUMEN}

Este estudio tiene como objetivo presentar aquellas constantes relacionadas con la visión y papel social de la mujer casada en los cuentos del Valle Nuevo (Egipto), las cuales fueron extraídas tras la realización de un análisis comparativo de temas, personajes y símbolos. En el mundo de estos cuentos, lejos de «vivir felices y comer perdices», la protagonista femenina casada sufre duras pruebas de fidelidad y lealtad por parte del esposo, es víctima de los celos de mujeres de su nueva familia y padece la presión de engendrar hijos varones. Son elementos comunes al resto de las tradiciones orales, con un marcado acento dramático. A este conjunto se agregan componentes de esta sociedad particular: la llegada de una nueva adversaria al hogar, la coesposa, una amenaza para la estabilidad y privilegios de esta y de sus hijos; la preferencia por el uso de símbolos concretos referidos a la mujer; y la descripción de costumbres locales, como es la boda tradicional. Todo ello ayuda a revelar el modelo social y valores específicos que transmiten estos cuentos, habida cuenta de que su narración es en sí un acto de habla que influye sobre su receptor: describen, a la vez que legitiman y perpetúan, en un flujo bidireccional.

\section{PALABRAS CLAVE}

Egipto; cuentos populares; actos de habla; sociología de la literatura; folklore

\section{RESUM}

Aquest estudi té com a objectiu presentar aquelles constants relacionades amb la visió $i$ el paper social de la dona casada en les rondalles de la Vall Nova (Egipte), les quals van ser extretes després de realitzar una anàlisi comparativa de temes, personatges i símbols. En el món d'aquestes rondalles, lluny de «viure feliços i menjar anissos», la protagonista femenina casada pateix dures proves de fidelitat i lleialtat per part del marit, és víctima de la gelosia de dones de la seva nova família i pateix la pressió d'engendrar fills barons. Són elements comuns a la resta de les tradicions orals, amb un marcat accent dramàtic. A aquest conjunt s'hi afegeixen components d'aquesta societat particular: l'arribada d'una nova adversària a la llar, la coesposa, una amenaça per a l'estabilitat i els privilegis d'aquesta i dels seus fills; la preferència per l'ús de símbols concrets referits a la dona; i la descripció de costums locals, com és el casament tradicional. Tot això ajuda a revelar el model social $i$ valors especifics que transmeten aquestes rondalles, tenint en compte que la seva narració és en si mateixa un acte de parla que influeix sobre el seu receptor: descriuen, alhora que legitimen i perpetuen, en un flux bidireccional.

PARAUles ClAu

Egipte; rondalles; actes de parla; Sociologia de la Literatura; folklore 


\begin{abstract}
This study presents a comparative analysis of themes, characters and symbols regarding the way married woman are depicted, the social expectations that are placed upon them and the constant themes that emerge in the folktales of the New Valley (Egypt). In the world described by these stories, far from "living happily ever after", the married female protagonist is subjected to harsh tests of fidelity and loyalty by her husband, is the object of the jealousy on the part of the other women in her new family, and is under pressure to produce to male children. These elements are common to all oral traditions, but this set of tales has specific features that reflect the society from which they emerge: the arrival of a new adversary in the home, the threat to the co-wife's stability and privileges and those of her children; the use of specific symbols relating to women; and the description of local customs such as the traditional wedding. All of these elements help to reveal the social model and values conveyed by these stories, whose telling is itself a speech act that influences the receptor in a two-way exchange; that is, the stories describe at the same time as they legitimize and perpetuate.
\end{abstract}

\title{
KEYWORDS
}

Egypt; folktales; speech acts; sociology of literature; folklore

REBUT: 3I/O8/2OI7 | ACCEPTAT: I9/O9/2OI7 
¿Y vivieron felices y comieron perdices?: la mujer casada en los cuentos populares...

\section{Introducción}

Este artículo se basa en un trabajo de campo en el que se recogieron 53 cuentos populares de tradición oral ${ }^{\mathrm{I}}$ grabados a once hombres y catorce mujeres de entre iI y 87 años; la mayoría narradores y narradoras de prestigio dentro de la comunidad, aunque en ningún caso profesionales. Fue realizado en dos localidades de la región egipcia del Valle Nuevo:² Barís (oasis de Jarga) y El-Qasr (oasis de Dajla), unas poblaciones no coherentes, en el sentido de que los orígenes de sus habitantes son diversos: el Magreb, Sudán, la península arábiga o el valle del Nilo. La historia, la demografía y la cultura de esta zona estuvieron condicionadas por haber sido lugar de paso de rutas caravaneras que cruzaban el desierto occidental egipcio y los aprovisionaban de mercancías. La mayor y posiblemente la más antigua de estas, que partía del Magreb hasta La Meca, fue utilizada por un porcentaje importante de los ancestros de los actuales pobladores del Valle Nuevo, quienes, tras haber cumplido con los preceptos de la peregrinación, decidieron establecerse allí. Otros factores a tener en cuenta son que se trata de una región aislada, enclavada en el desierto y con una importante impronta de la cultura beduina, además de que ha sido tradicionalmente marginada debido a su lejanía del resto de Egipto. Esta discriminación también se extiende a los estudios científicos, cuyo protagonista ha sido casi en exclusiva el valle del Nilo. Por otra parte, este aislamiento también contribuyó a que se preservaran muchas de sus antiguas tradiciones populares.

I El presente estudio es fruto de mi tesis doctoral «Cuentos populares y sociedad en los oasis del Valle Nuevo (Egipto)», presentada en dos tomos en la Facultad de Filosofía y Letras de la Universidad Autónoma de Madrid y leída el 26 de octubre de 20I6. En el tomo II se encuentra el corpus transcrito y traducido al castellano y los audios adjuntos en formato MP3. Disponible en línea en: <https://repositorio.uam.es/handle/Io486/677699> [fecha de consulta: septiembre de 20I7].

2 El Valle Nuevo (en árabe egipcio $E l$-Wādì el-Ğedìd) es una de las veintisiete gobernaciones de la República Árabe de Egipto. La región forma parte de la extensión oriental del desierto del Sáhara, del desierto libio, que sigue su recorrido desde la meseta libia del Fezzán hacia el este, adentrándose en las fronteras de Egipto hasta el valle del Nilo, donde toma el nombre de Desierto Occidental y ocupa las dos terceras partes de este país. Para más información a este respecto, consúltese Seoane (20I6a: 47-52). 


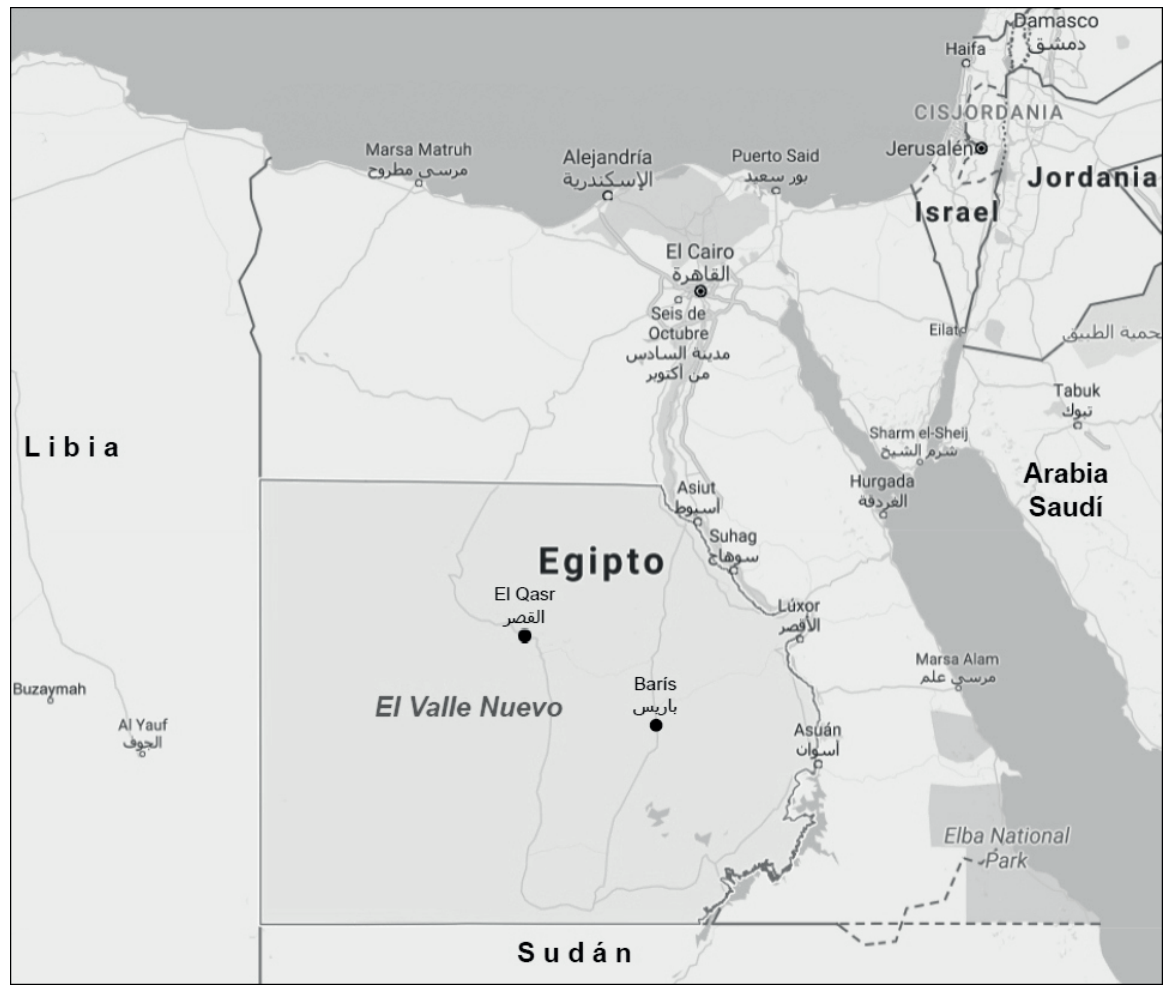

(Fig.I): Mapa de la situación geográfica del Valle Nuevo, adaptado a partir de Google Maps.

Tras la compilación de estos relatos inéditos, su transcripción y tradición, quise hallar qué particularidades motivaban que estos relatos fueran propios de la tradición oral de esta región y posteriormente descubrir y difundir su contenido sociocultural. Para ello, en primer lugar he aplicado la tipología del catálogo internacional de Aarne-Thompson-Uther ${ }^{3}$ The Types of International Folktales (Uther 2004) y del catálogo árabe de Hasan El-Shamy (2004). Una vez localizado el tipo o subtipo al que pertenecían los Cuentos del Valle Nuevo (CVN), rastreé cuáles eran sus diferencias con versiones de otras tradiciones vecinas (desde el valle del Nilo hasta llegar a Europa), concluyendo que se trataba de versiones adaptadas al contexto árabe del patrimonio universal de los cuentos orales, pero con temas, personajes y símbolos recurrentes que desvelaban sus preferencias y transmitían una concepción social concreta.

3 La principal aportación de la escuela de Helsinki al estudio del cuento folklórico fue el catálogo universal del cuento folklórico, reconocido internacionalmente como el sistema estándar de catalogación y clasificación universal de los cuentos populares. A raíz de esta iniciativa, numerosos folkloristas se han dedicado a la laboriosa tarea de compilar y catalogar los cuentos existentes en diversas regiones para incluirlos en este catálogo internacional y poder rastrear cómo se manifiestan los mismos tipos y motivos en diferentes zonas geográficas. Es el caso de Hasan El-Shamy con los cuentos árabes. Para más información, consúltese el capítulo I.2.I., «Método histórico-geográfico y comparativista», en Seoane (2016a). 
¿Y vivieron felices y comieron perdices?: la mujer casada en los cuentos populares...

Pretendo describir estos patrones y asociarlos con una de las funciones intrínsecas en estos cuentos, que es la de influir sobre el receptor, derivada de la idea de que los cuentos populares son actos de habla ${ }^{4}$ a través de los cuales se crea un mundo social. Son parte de los intercambios lingüísticos de los hablantes de esta sociedad, vehículo de un entramado social que se consuma y legitima en ellos, en donde el narrador hace partícipe a su audiencia en la construcción de un mundo posible creado en el cuento y en el que los roles de género se encuentran perfectamente definidos, según una concepción tradicional. De este modo, en los CVN, al igual que en el resto de las tradiciones cuentísticas orales, interactúa una materia universal con las realidades sociales que toman forma en estos actos de habla.

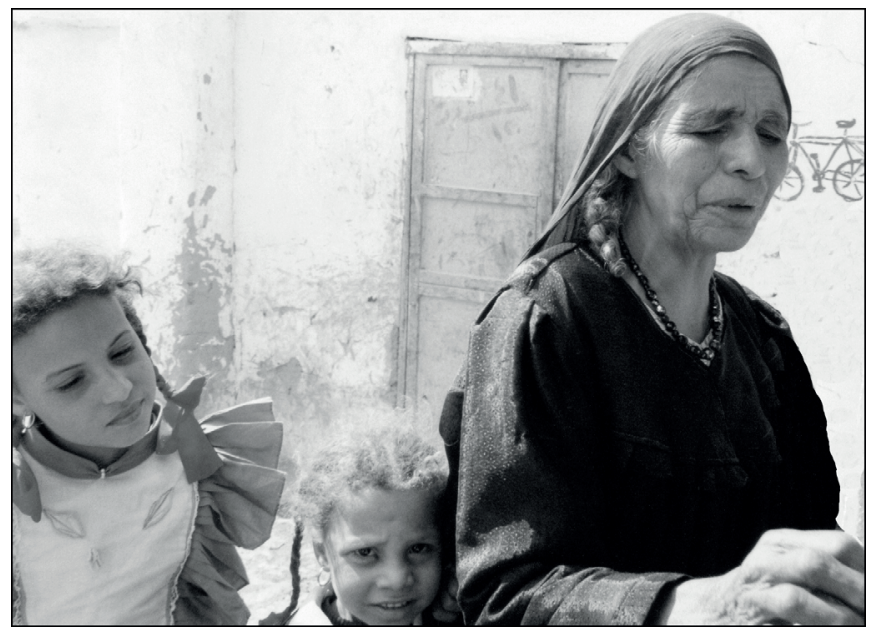

(Fig. 2): Fațma Mohamamed, una de las narradoras de El-Qasr y niñas de su familia.

La mayoría de los CVN incluyen elementos maravillosos de carácter simbólico en los que se narran acciones y costumbres referidas a una sociedad del pasado, que no se aleja demasiado de la actual a pesar de su avance formal. En estos relatos, la mujer juega un papel especial y es particularmente representativa la visión que ofrecen estas historias de los personajes femeninos desposados, por lo cual me centraré en ellos, aplicando una perspectiva de género 5 al estudio de los CVN. De este modo, presentaré aquellas constantes, ${ }^{6}$ extraídas tras el citado análisis y muchas veces intercomunicadas, sobre la visión y papel de la protagonista casada en la sociedad a través de los CVN.

4 La teoría del análisis del discurso sobre los actos de habla expuesta por Austin (I982) y Searle (I994) defiende la función de la lengua como uso y no como producto, aportando la debida relevancia al habla y al uso lingüístico contextualizado.

5 Para más información sobre los estudios sobre el cuento folklórico desde esta perspectiva y un ejemplo aplicado, véase Oriol (2017).

6 Para comprobar los otros elementos recurrentes fruto del análisis comparativo, consúltense los capítulos 5.4., «Personajes», y 5.5., «Temas», en Seoane (20I6b). 


\section{Los personajes femeninos casados}

En el mundo de los cuentos populares la principal aspiración de la mujer soltera es casarse, y así suelen terminar los cuentos maravillosos. Su colofón es una fórmula de cierre que augura una vida feliz y próspera después del matrimonio, pero ¿qué ocurre «realmente»7 en el mundo de los CVN tras esa promesa de felicidad después de la boda?

La fórmula clásica de cierre de los cuentos de la tradición europea, «vivieron felices y comieron perdices», tiene su equivalente en los CVN en «estables y prósperos vivieron e hijos e hijas tuvieron», según una traducción en la que he buscado la rima. Literalmente: «Y vivieron en la estabilidad y los vegetales y engendraron niños y niñas». ${ }^{8}$ Es uno de los esquemas más usados en los CVN y una fórmula compartida con la mayoría de los cuentos maravillosos egipcios con final feliz. En esta se incorpora un elemento particular que plasma las aspiraciones de la sociedad de este país: el deseo de que tengan hijos para que la dicha sea completa. En esta fórmula no se menta la felicidad y, ciertamente, «la realidad» de los personajes femeninos de los cuentos tras el matrimonio dista mucho de lo que resume la frase de la fórmula de cierre.

El denominador común de los personajes femeninos en los CVN suele ser su pasividad y sumisión a la voluntad de sus padres, y una vez casadas, a la de sus maridos, siguiendo un modelo patriarcal tradicional y las normas islámicas. Pasan a ser meras criadas de sus esposos y engendradoras de sus hijos, como ilustra el cuento 8, Manoscortadas, donde el protagonista se dirige a su hermana: «Tráeme a una mujer con quien casarme para que te sirva, nos haga la cena y cocine para nosotros, limpie la casa y haga todo [...] Tráeme a una mujer, cásame con ella y en vez de que tú hagas para mí todo, ella vendrá y hará para mí todas nuestras cosas, me lavará la ropa, me traerá la comida y me traerá todo».

En general, la esposa no tiene el derecho de tomar ni participar en las decisiones importantes y la lealtad y sometimiento a su esposo deben ser incondicionales, por muy injusta que sea la situación creada. Los ejemplos más ilustrativos de manifestación de este proceder se hallan en los cuentos 34 y 35, El rey y la mujer del visir, donde se defiende la obediencia de la mujer a su marido, incluso si este se comporta de manera violenta y despótica. En el relato 32, La esposa paciente, el cónyuge finge matar, cocinar y comer a sus hijos recién nacidos ante su esposa, para así probar su confianza ciega y vasallaje a su voluntad, y por lo tanto, comprobar que es una buena esposa, digna de la dote que pagó por ella.

La ambición de la mujer casada, tras haber sido víctima de diversas injusticias por diferentes causas, es exclusivamente recuperar su posición en el hogar, sin siquiera esperar una compensación por los malos tratos recibidos por su marido, suegra o/y cuñada.

7 Entiéndase como realidad dentro del cuento.

8 En su transliteración del árabe: wa- 'āšū fî̀-t-tabāt wa-n-nabāt w jallafū șobyān w banāt. 9 La numeración de los cuentos corresponde a la de la Tesis (Seoane 2or6a y 20I6b). 
¿Y vivieron felices y comieron perdices?: la mujer casada en los cuentos populares...

En lo que se refiere a la protagonista sobrenatural femenina de los CVN, la ŷinniyya,$^{\text {IO }}$ al igual que la mayor parte de las princesas del CVN, es representada como un personaje pasivo que es objeto de la voluntad caprichosa del raptor, que la toma por esposa, al tiempo que de la barbarie de su padre (7, El bonete de la invisibilidad), o por una anciana alcahueta (3-4, La anciana y su hija).

A la ŷinniyya de los cuentos 3-4, La anciana y su hija, su marido le da instrucciones sobre el mejor modo de demostrar su valía ante vecinos y allegados: «Trae una jarra, trae para que almuerce, trae té para que beba [...]. Sacrifica este camello, córtalo y cocínalo. Yo [...] salgo a rezar mientras tú preparas este camello y lo acabas para el banquete».

Igualmente, en la ŷinniyya del 6, El estornino, cuyo principal atributo es su belleza extraordinaria, una vez desposada, su virtud pasa a ser su capacidad para ayudarle en las duras labores agrícolas.

Los defectos que se le suelen achacar a la esposa son el no ser capaz de guardar los secretos de su marido, por lo tanto, de poder destruir sus planes, y su tendencia a la manipulación. El esposo debe estar en permanente alerta para evitar que lo maneje, bajo pena de sufrir terribles consecuencias. Un ejemplo de ello sucede en el 22, El monstruo y los gū l, donde dos esposas avaras y codiciosas manejan a sus maridos con resultados fatales para ambos: uno muere y el otro acaba sobreviviendo de la mendicidad.

Por último, cabe subrayar que la infidelidad de la esposa es el tema principal de 34-35, El rey y la mujer del visir (ante la mera sospecha de infidelidad, sin mediar palabra, le pega una paliza y la echa de casa), y 5I, El calvo y la esposa infiel (cuando el marido y su sobrino la descubren, le dan de comer carne de burro como castigo ejemplar; se la compara así con este animal):

Enfermó y le vino una enfermedad que la hizo quedarse en cama y estuvo así una larga temporada [...] Después vino el doctor a su casa [...] Le dijo que tenía que comer carne, pero no había carne en aquel momento. [...] y le dieron de comer carne de burro y después de que mejorara y se levantara, le dijeron:

-Nosotros te dimos de comer carne de burro, carne de burro [...].

Y se murió la señora después de haber comido carne de burro.

Io Los ŷinn son criaturas sobrenaturales de la mitología árabe e islámica. Son seres incorpóreos, invisibles y, generalmente, malvados, nacidos del fuego, que se organizan en confederaciones ocultas en lugares apartados, con sus animales y tesoros. En su versión femenina, son buenas con los humanos. Para más datos sobre este personaje, consúltese el capítulo 5.4.I.I.3., «La ŷinniyya», en Seoane (20I6a). 


\subsection{Las bodas}

Un elemento muy recurrente en los CVN es la descripción de la boda (completa o partes de ella), ${ }^{\text {II }}$ la cual se celebra según «la tradición del Profeta» y las costumbres locales. Es la última recompensa de héroes y la aspiración vital de las heroínas, de modo que la misma $g \bar{u} l a,{ }^{12}$ que le chupa la sangre a la protagonista $(23$, La güla y el pan), cuando cae en el hoyo pide a la muchacha que la saque de allí a cambio de hacerse cargo de «una boda para sus hijos».

Quince mujeres, de dieciocho relatos en los que las mujeres se casan, no deciden su boda, sino que es el hombre el que realiza la elección o directamente son raptadas por este. Cabe señalar que en el mundo auténtico de estos oasis, se puede aludir al marido como «aquel que adquiere a su esposa», un tipo de expresión de la que quedan restos depositados en la conciencia popular sobre formas antiguas de unión conyugal, como era el matrimonio por compra o por captura durante los tiempos en los que tenían lugar luchas de tribus primitivas en estos oasis. ${ }^{13}$

Como ya se ha señalado, la razón por la que son escogidas es su belleza, aunque en tres ocasiones resulta ser por otras cualidades distintas: su inteligencia y recursos, como saber bailar, tocar la percusión y cantar, en 24, Las tres hermanas y el gūl; tejer, en 37-38, Senāys la Ingeniosa; y ser paciente, ${ }^{14}$ en 32, La esposa paciente.

Los CVN constatan la antigua tradición de casarse entre primos paternos o con alguien del mismo linaje, según se comprueba en el 42, La princesa y su primo paterno, donde la novia se resiste a casarse con alguien diferente. Además, en la sociedad del Valle Nuevo, lo normal es que se casen las hermanas mayores antes que las más jóvenes, pues tradicionalmente es un desprestigio que una mujer no esté casada a una cierta edad (2, Los siete gozos y las siete penas).

Por otra parte, hay dos casos en los que la boda es utilizada como acto de venganza del pretendiente rechazado hacia la muchacha, quien así gana control sobre ella para que aprenda a aceptar su papel como esposa dócil (4I, Es-Sett Selēs: «Después la tomó y se casó con ella para enfadarla»).

\subsubsection{La boda tradicional}

En la boda, la gran protagonista y foco de atención de las diferentes partes que la componen es la novia. La mayoría de estas etapas del proceso de la boda tradicional en estos oasis se plasman a lo largo de los CVN, con especial hincapié en que toda pareja debe legitimar su unión siguiendo los preceptos islámicos. Es 3-4, La anciana y su hija, el que da a conocer el mayor número de partes de esta ceremonia en el Valle Nuevo, como se describe a continuación.

En primer lugar, se retrata a un pretendiente que cumple con los preceptos del islam y, como valor añadido, su origen es noble (el hijo del sultán conoce la existencia de la muchacha con la que se quiere casar, mientras se dirige a la mezquita a realizar la oración de la mañana). Se especifica que es una bella muchacha de

II Se mencionan partes de la boda en nueve cuentos.

I2 El gūl y la gūla son los equivalentes del ogro y la ogresa de la tradición europea. Son seres de la mitología árabe, de aspecto monstruoso, que actúan como adversarios de héroes o heroínas humanos, con los cuales se comportan maliciosamente y buscan chupar su sangre. Véase apartado 5.4.4.I., «El gūl y la gūla», en Seoane (2OI6a).

I3 Información proporcionada por el folklorista egipcio Fares Khedr en conversación con él. I4 En este cuento se relaciona la paciencia con la inteligencia. 
¿Y vivieron felices y comieron perdices?: la mujer casada en los cuentos populares...

tez blanca ${ }^{15}$ y alejada de la vista de los hombres («Cuando se lava la cara, que es blanca como la leche, se demuestra que ella es como la luna y el sol», «Ella no sale del interior de la casa y nadie la ha visto nunca»). Pide la mano de la muchacha a su supuesta madre, a falta de que tenga un padre, sin contar con el albedrío de la muchacha: "Pido el acercamiento ${ }^{16}$ a tu hija, señora Zeynab. Quiero casarme con ella. ¿Me la vas a dar o no?" [...] Trajo a los invitados, leyeron la fātiha ${ }^{17}$ y nadie la vio. Vino toda la gente del pueblo de esta. Vinieron con ropas y trajeron cosas para la novia».

Le toman las medidas a la novia para su ropa de boda («Trae a la muchacha. Déjanos que le marquemos la tela que le hemos traído»), se fija la noche de bodas («La noche de bodas será, como si dijeras, el próximo jueves; la próxima semana») y celebran el banquete. Antiguamente, la procesión por el pueblo de la novia se hacía subiéndola sobre un camello (25, La gūla y el pozo mágico) o una yegua, pero en este, quieren subirla en un coche para darle más importancia y actualidad al acto («Déjanos subirla en un automóvil porque no la vamos a montar en una yegua ni nada de eso»). Antes de la noche de bodas, las mujeres la llevan a bañarse («Déjanos lavarla en los pozos, en el manantial, en el pozo en lo que sea; en el agua»).

En el cuento I9, Lūlì la hija de los gūl, se describen también partes del proceso de la boda tradicional y se citan los regalos que hace el padre de la novia tras haberla acordado: regala a cada uno un ternero para cebar, un bonete y unos calzones para coser y vestir en la boda. Además, en este relato se organiza una gran fiesta, una procesión en la que rodean al novio, sumando a la procesión de la novia.

Asimismo, en 25, La gūla y el pozo mágico, se menciona la costumbre local de la utilización de un tamiz como símbolo de bendición sobre el matrimonio: «Niña, ve y tráeme el tamiz de casa de la gūla para que tamicemos la luz sobre tu matrimonio». También era un ritual extendido por toda la geografía egipcia el que los amigos del novio lo llevaran a bañarse con ellos y le vertieran el agua a través de un tamiz para bendecir su matrimonio. Para J. Chevalier (I986: 974), el tamiz es el instrumento de la elección, cuyas mallas son tanto más tupidas cuanto más severas son las exigencias para uno mismo y para los demás, y arroja luz purificada a través de su filtro. Uno de los rituales que tienen lugar en las bodas de la zona consiste en que las mujeres se reúnen y cantan canciones propias de estas celebraciones, mientras criban el trigo, cuya harina se utilizará para cocer el pan de la boda. También en el cuento ig se hace referencia a la ceba de un ternero para el banquete de bodas.

En lo que se refiere al ajuar de la novia, se mencionan las joyas que adornan a la novia: aretes, ajorcas y anillos, sobre los que se insiste en el 25, La gūla y el pozo mágico, como marca de singular importancia para convertirse en una verdadera novia:

I5 El ideal de belleza femenino en la tradición árabe se corresponde con una mujer de tez blanca, cabello negro largo, ojos negros, mejillas sonrosadas y baja estatura.

I6 El «acercamiento» (el-'orba, en dialecto egipcio) es uno de los pasos del proceso de matrimonio en el que se pide la mano de la mujer.

I7 Primera de las azoras o capítulos en que está dividido el Corán. Su lectura consuma el contrato de matrimonio musulmán. 
Él tenía otra mujer que tenía una hija. Cuando [esta] desechó la seda, la otra muchacha la limpió, bordó con ella su ĝalābeyya, ${ }^{\mathrm{I}}$ cogió sus ajorcas, joyas y muebles y se llevó todas las cosas de la otra muchacha para casarse ella. [...]

- ¡Oh, pozo! ¡Oh, pozo! [...]

Salieron de él muchas ajorcas, muchos anillos y [...] la muchacha se convirtió en una novia.

Las mujeres jóvenes son tratadas como medio de mejora de la posición social y económica de la familia, a cuyo precio se le llama «dote», según muestra el cuento 43, Eššsăter Mohammed y el encargo: «Quiero a tu hija para mi hijo. [Le contestó:] Si pagas cien libras como dote para la muchacha, te llevas a la muchacha».

La dote en Egipto se encuentra supeditada a la categoría social de ambas partes y a la tradición heredada, y suele consistir en dinero o cabezas de ganado. Cuando se registra el matrimonio, se cita en los documentos que la dote se dividirá en una pequeña cantidad anticipada; mientras la segunda parte queda pendiente de pago en caso del divorcio y se la considera una especie de aval tácito para garantizar la continuidad del matrimonio. La dote suele ser susceptible de regateo, en el que, a veces, un hombre mayor debe zanjar la cuestión.

\subsubsection{El símbolo de la muñeca}

Uno de los símbolos más significativos en los relatos de los oasis del Valle Nuevo es el de la muñeca de madera o masa, utilizado como representación de la mujer pasiva y sustituta de una novia que es obligada a aceptar un marido impuesto. Así se ejemplifica en los cuentos 3-4, La anciana y su hija, donde la supuesta madre encarga a un carpintero hacer una silueta de madera cubierta con una galäbeyya que reemplace a su supuesta hija. De esta manera mantiene su engaño en la recepción de los invitados a la boda y en la procesión, figurando a la novia inerte e inanimada, mero objeto de decoración y exhibición durante la ceremonia: «Trajo esta madera, ¿y dónde la colocó? Al lado de la gente que estaba allí y ella se quedó junto a ella asimismo. Después, llegó el momento de la procesión de la novia, la llevaron en procesión y luego, se fueron».

En 37-38, Senāys la Ingeniosa, la protagonista elabora una muñeca de harina y azúcar de su tamaño para que ocupe su lugar en la noche de bodas y así evitar que su marido la asesine. Posteriormente, este le corta la cabeza a la muñeca, pero se arrepiente al advertir «su dulzura»: «Salió volando [y un pedazo fue a parar a su boca] y dijo: “¡Ay, Senāys! ¿Cómo sería tu dulzura en esta vida, si en la otra es así?”».

En la historia 32, La esposa paciente, la protagonista modela una muñeca de masa para poder hablar con alguien y usarla como confidente inerte de sus penurias. Será su medio de desahogo y recipiente de una desesperación sufrida en silencio y en solitario.

No obstante, al contrario de la protagonista siempre pasiva de 3-4, La anciana y su hija, la heroína de los 32 y 37-38 toma decisiones para defenderse del marido asesino.

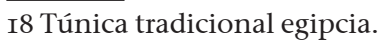


¿Y vivieron felices y comieron perdices?: la mujer casada en los cuentos populares...

\subsection{Las adversidades de la esposa en la vida matrimonial}

La vida matrimonial de la esposa de los CVN está llena de episodios crueles, dramáticos y sanguinarios, en los que narradores y narradoras describen las calamidades que sufren en especial las protagonistas femeninas y que frecuentemente constituyen el conflicto a solucionar de la historia. En general se relacionan con la calumnia a la esposa por parte de una mujer de la familia del marido o/y la expulsión del hogar.

Uno de los mejores ejemplos es lo que le sucede a la protagonista del cuento 8, Manoscortadas. Acusada de falsedades, después de que su hermano le hubiera cortado las manos, su marido la expulsa de casa y le cuelga un recipiente al cuello para que viva de la caridad. Finalmente es Dios quien se compadece de ella y ayuda a restituir su posición en el hogar.

El tema de la mujer calumniada ${ }^{\mathrm{I}}$ es muy común en los cuentos populares y la protagonista acostumbra a ser una mujer casada. En dos de los CVN (8, Manoscortadas, y Io, Las palomas), aparece el motivo de la difusión de la falsa noticia, por parte de una mujer celosa y envidiosa de la familia de su marido (suegra, cuñada o ambas), de un parto de animales (perros o palomas) por la esposa. La mujer adversaria sustituye a los recién nacidos por animales para que el marido o hermano la repudie, la eche de casa, la encarcele o la mate.

Como he mencionado, en el cuento 8, Manoscortadas, la protagonista es expulsada de su casa y castigada injustamente dos veces (por su hermano y por su marido). En ambas ocasiones son manejados por la malicia y celos de mujeres de la familia del marido que difaman a la protagonista.

Otro asunto tratado es el de la falsa infidelidad de la esposa, como sucede en 34-35, El rey y la mujer del visir, donde la mujer virtuosa es condenada injustamente por adulterio, a raíz de la intrusión del rey en su casa, el cual deja su anillo bajo la almohada. Sin mediar palabra, el marido le da una paliza y ella se refugia en casa de su padre, que será quien solucione la disputa para que la hija pueda volver junto a su marido.

La protagonista del 7, El bonete de la invisibilidad, es asimismo castigada arbitraria y violentamente, esta vez por su padre, por casarse con un hombre que no era de su posición social, cuando en realidad había sido raptada.

Otro de los CVN más representativos de la brutalidad con la que se trata a las esposas es el 32, La esposa paciente, donde el marido obliga a su mujer, a punto de dar a luz, a ir a buscar ella misma a la partera y arreglárselas sola; finge matar, cocinar a sus hijos recién nacidos y comérselos ante su esposa, para probar su paciencia y sometimiento a la voluntad de su marido:

Este hombre fue y dijo:

—Toma, horneador. Ve, cógela, dásela al restaurante, mátala, cocínala y tráesela.

— ¡Ahhhh! La niña está cocinada y comida.

Le dijo a la mujer:

-Come tú también de ella.

-No. Yo no como.

I9 Para más información sobre el tema de la mujer calumniada, consúltese Noia (2015: 8I-94). 
Dejó que fermentase ${ }^{20}$ al aire y se la trajo.

—Coge de su cadera. Coge de su brazo, coge de aquí, coge de allí.

Le dijo ella:

- No.

Él se la comió entera.

\subsection{La procreación y los niños}

Es reseñable que, en los comienzos de numerosos CVN donde se presenta la situación del protagonista masculino o femenino, se invisibiliza a sus madres: se inicia con la muerte de esta, o simplemente no se la menciona, siendo el padre el único progenitor citado como personaje. La siguiente tabla permite comprobar cómo, en la narración de los 53 CVN, 4I arrancan a partir de un matrimonio, 27 de los cuales se refieren a un matrimonio con hijos y dentro de estos solo en I4 se menciona al padre y no a la madre:

\section{Cuentos del Valle Nuevo (total: 53)}

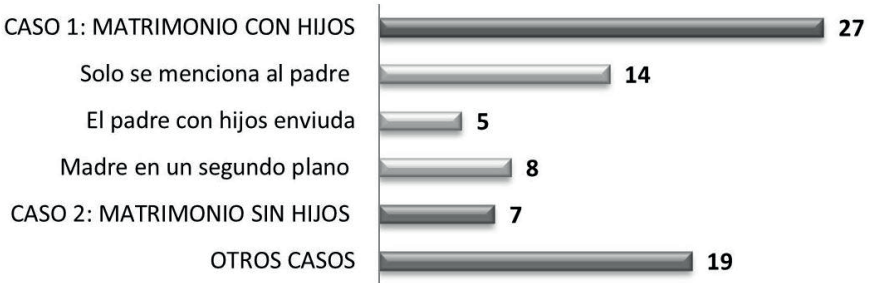

Una de las virtudes principales de una buena esposa es que sea fértil y que los hijos «que le dé a su marido» sean varones. En 8, Manoscortadas, la suegra de la protagonista únicamente la quiere como procreadora de niños para su hijo, el príncipe. Se considera que tener progenie es una bendición otorgada por Dios («Nuestro Señor la tomó de su mano y tuvo dos niños»). En 39-40, El hijo del sultán y su esposa, se pueden hallar diferentes alegatos a favor de la maternidad: "Cuando me dijiste que moriría por no tener hijos, me dije: "Tengo que intentarlo todo [pues] el adorno de la palmera sus dátiles son y el adorno de la mujer sus hijos son"».

O amenaza y menosprecia a la mujer estéril, según refleja el cuento 39, El hijo del sultán y su esposa: «Se casaron y no tuvieron hijos [...] y entonces le dijo él: "Por Dios, que voy a dejar que te mueras por no tener hijos. Me iré de viaje"».

Tanto en los cuentos citados como en el 4I, Es-Sett Selēs, se justifica el abandono de la esposa que no tiene hijos, lo cual supone suficiente argumento para que el marido tome otra esposa. De hecho, en el mismo relato, la esposa se disfraza y engaña a su esposo para tener sexo e hijos con él. Una vez que lo logra, recupera su posición en el hogar, generalmente ayudada de modo activo por sus hijos pequeños. Estos unas veces son enviados por la esposa a molestar en la boda del

20 Hace creer a la esposa que es la carne de su hija. El cuento no menciona la naturaleza de la carne que utiliza en su lugar. 
¿Y vivieron felices y comieron perdices?: la mujer casada en los cuentos populares...

padre con otra mujer y otras veces son ellos los que la hacen reaccionar para que recuperen su lugar legítimo, como en 34-35, El rey y la mujer del visir:

Se casó con otra más y dijeron [sus hijos]:

— ¿Cómo es que se va a casar con una tercera y nos ofrece [a nosotros] los desperdicios y nos ofrece eso? ¿Por qué no hablas? La noche que la traigan de la casa de su padre, queremos dejarte allí y que hables en la casa de la novia.

Cogieron y se marcharon. Fueron a traer a la novia. Ella fue con ellos y tiraron de [la novia]. Tiraron de ella Șūr, Manșūr y Medanet ar-Rasūl; uno de esta manga, el otro [tiró] de la otra y el otro del extremo del pañuelo.

El motivo que aparece en siete cuentos a lo largo de los CVN, «Los bienes son de nuestro padre y los desvergonzados ${ }^{2 \mathrm{I}}$ nos echan», representa la cuestión de la herencia y se utiliza para manifestar la injusticia de que otros ocupen su lugar legítimo. En estos cuentos se pone de manifiesto la reivindicación de los hijos del reconocimiento de la paternidad, así como el derecho al disfrute de sus posesiones.

El no tener descendencia es asimismo causa de tristeza y soledad en la vejez de la anciana de 3-4, La anciana y su hija, quien finge tener una hija, y no una hermana como en otras versiones árabes del mismo cuento. De esta manera podrá casarla con un príncipe, asegurarse el futuro y elevar su estatus.

Por otra parte, se insiste en el problema de tener solo hijas, lo cual en el cuento 2, Los siete gozos y las siete penas, es motivo de sumo desconsuelo para el padre y de burla por parte de su hermano, que sí tiene hijos varones y constituyen su fuente de orgullo. En los cuentos 22, El monstruo y los gū l, y 27-28, Abū Șarra, los problemas de los protagonistas se acrecientan por tener una familia numerosa compuesta únicamente por niñas. Es el caso del cuento 27-28, donde una de las gūla (la madrastra) echa de casa al marido cuando ve que únicamente tiene hijas.

\subsubsection{El símbolo del jardín y el jardinero}

La simbología universal del jardinero (el hombre) posee la connotación sexual de aquel que coloca la simiente en el jardín (la mujer) y lo hace florecer, derivada de los deseos del héroe soltero por casarse y del héroe casado por lograr descendencia, lo cual supone un recurso persistente en los CVN. Hay que destacar que mientras en las otras versiones árabes del mismo cuento no aparece, sí lo hace en la versión del Valle Nuevo. En los cuentos I7-I8, El rey y sus herederos, la madre del anfitrión es forzada a reconocer su infidelidad para demostrar el origen bastardo del anfitrión: «Hijo mío, tu padre es el dueño de las tierras y cuando, en nombre de Dios, se fue, mi rey tomó lo del jardín, tomó lo del jardín [...]».

En 34-35, El rey y la mujer del visir, se añade el símbolo del león para representar al rey que entra en el jardín:

-Yo tuve un jardín que embellecí, reverdecí, regué y se volvió fértil y perfecto. Se lo entregué al excelentísimo visir para que lo cuidara y no lo estropeara. Pero lo abandonó y sus ojos se consumen llorando porque no

2I Este motivo cuenta con diversas variantes en las que varía principalmente la manera de referirse a los que ocupan su lugar (gente, gorrones, desvergonzados). 
es regado. Se marchita. Se marchita y se le caen las hojas. Cuando llegó el león y entró, no dejó que lo regara [...].

- He dicho la verdad y vi su tierra, pero no fue arrancada ni una hoja de su tierra.

En el relato I9, Lù lì la hija de los gūl, la heroína se convierte a sí misma en jardín y al héroe, en jardinero, para burlar y escapar de sus padres $g \bar{u} l$. Mientras tanto, en el I2, El caballo verde, el héroe escoge como labor para servir al rey la de jardinero, argumentando que también era el oficio de su padre.

Otros símbolos que aluden a la procreación en los CVN y reflejan la importancia que se da a este acontecimiento son un odre vacío (como símbolo de la mujer sin hijos), un pedernal sin fuego (hombre sin simiente) o una palmera sin dátiles (mujer sin hijos).

\subsection{Las adversarias de la mujer casada}

La mayoría de las adversarias de la protagonista casada en los CVN, tanto reales como sobrenaturales, pertenecen al género femenino. La suegra y la cuñada son las principales adversarias reales. En el plano mágico, la enemiga más temeraria es la $g \bar{u} l a .^{22}$

\subsubsection{La suegra y la cuñada}

La suegra es la principal adversaria real de la protagonista. Se dibuja como un ser malvado que combate a la heroína, para lograr el poder y control del hogar, puesto que «solo puede haber una matriarca en la casa familiar», como ocurre en el cuento Io, Las palomas. Una segunda razón es asegurar la herencia de sus hijas, como en el 9, La esposa reemplazada del hijo del sultán, en el que expulsa a la esposa, la sustituye por su hija (hermana del protagonista masculino) y la deja en una situación de indefensión. Y la tercera es que solo quiera a la muchacha como recipiente para engendrar hijos (8, Manoscortadas).

Suegras y cuñadas son retratadas como esposas celosas que utilizan a sus maridos para lograr sus propósitos. Además, procuran deshacerse de los hijos de la protagonista, para lo cual la acusan de haber engendrado animales en lugar de niños, según he referido previamente. En el ıo, Las palomas, la cuñada también intenta hacer desaparecer a los hijos de la protagonista convirtiéndolos en palomas y a ella la desaloja de la casa. Una de las cuñadas de los CVN, representada como extremadamente malvada, es la del cuento 8, Manoscortadas, que intenta culpar a la heroína del infanticidio que ella misma había cometido.

22 Para información detallada sobre estos personajes y su función como adversarios mágicos, véase el capítulo 5.4.4.I., «El gūl y la gūla», en Seoane (20I6a). 
¿Y vivieron felices y comieron perdices?: la mujer casada en los cuentos populares...

\subsubsection{La coesposa}

La rivalidad y celos hacia las coesposas siempre han sido una temática presente en los cuentos egipcios debido a la existencia de la poligamia en esta sociedad, y así se plasma también en los CVN, donde unas veces aparece como una figura virtual amenazante (en dos cuentos), otras veces como una figura tangible con la que debe convivir (en dos cuentos), y otras, como una figura «real» por la que es sustituida y expulsada del hogar (en siete cuentos), a veces acompañada de sus hijos.

En las historias del primer caso, se hace visible el miedo de la esposa a que el esposo se case con otra y mermen las atenciones hacia ella y sus hijos o incluso la abandone, como en 3-4, La anciana y su hija. En este ejemplo, el marido repudia a su mujer ŷinniyya y se casa con otras dos mujeres porque esta no habla, hasta que un día no consigue contenerse y responde a los insultos de las coesposas. Al enterarse, el hijo del sultán se divorcia de las otras y renueva sus votos con ella.

En el segundo caso (47-48, La esposa del espejo), la protagonista teme que su marido despose a otra mujer más guapa («que tenga un cabello más bonito»). Esta esposa ocupa su tiempo en las labores domésticas y en preocuparse por si su belleza pudiera ser superada ( ¿ ¿Mi cabello es tan bonito como el tuyo? ¿Has visto cómo me he pintado los labios?», «¿Soy yo la guapa o lo eres tú? Dime ¿tú eres la más guapa o lo soy yo?»). Todo la historia gira en torno a su necedad e ignorancia con el fin de divertir al oyente, pero al mismo tiempo el narrador masculino lo concluye con una fórmula de cierre que vincula él con la realidad poniendo por medio a Dios («Se agotó el cuento y Dios Sublime ha dicho la verdad»).

En la tercera situación, puede ser el propio marido el que expulse de casa a su esposa o que sea la suegra y/o la cuñada, y debe luchar para recuperar su lugar en el hogar y, en su caso, también el de sus hijos, como en el citado cuento 9, La esposa reemplazada del hijo del sultán, en donde la suegra disfraza a su hija tuerta, la reemplaza por la esposa verdadera y se queda embarazada. Al final el héroe descubre el engaño, echa de casa a su madre y a su hermana y restituye a su esposa.

Puesto que en Egipto la herencia la recibe el primogénito varón, las nupcias con otra mujer generaban tensiones, porque se temía que la nueva esposa influyese en su marido para que legase los bienes a uno de sus hijos en detrimento de los hijos del primer matrimonio.

\subsubsection{La gūla}

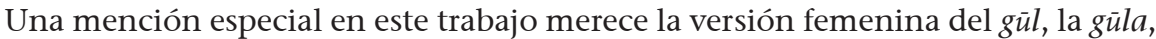
cuando su función es la de representar a la madrastra o a la suegra malvada. Este último es el caso del cuento 9, La esposa reemplazada del hijo del sultán, donde la suegra de la protagonista puede cambiar su cara y piel para conquistar a su propio hijo y eliminar de la casa familiar a la esposa.

En la otra faceta de este personaje que atañe a este artículo, mantiene sus atributos aterradores propios, pero está casada con un humano (27-28, Abū Șarra), al que utiliza para poder comerse a las hijas de este. Para Hasan El-Shamy (2005: 362-363), estos cuentos de mujeres violentas servirían como una advertencia ante las posibles intenciones del marido de buscar una nueva esposa, sumado a la tendencia inherente a todos los seres vivos de transmitir su propio material genético a las generaciones futuras. De hecho, en este ejemplo, después de que la gūla logra comerse a una de las niñas, corre tras su marido para igualmente ser engullido. 
Pero ¿cómo es este ser con el que se amedrenta tanto a ambos cónyuges como a su descendencia y cómo se describe en los CVN? Por lo que se refiere particularmente a la versión femenina de este ser fantástico y de acuerdo con la descripción que hace 'Abd el-Hakīm (I985:38), la gūla es una hembra gorda y fea, que, como el $g \bar{u} l$, vive en un intento constante de cazar seres humanos, asesinarlos y comerlos. Nos la encontramos en los cuentos de magia como dueña de una casa aislada, en donde su escenario de acción es la cocina, y en ocasiones, con un marido humano e hijastras, que le servirán de comida. Con frecuencia, cuando se nombra a la gūla se la llama «madre gūla» o «tía (paterna) güla», como en el 23, La gūla y el pan. La folklorista egipcia Nabila Ibrahim (I994: 240) sugiere que el símbolo de «la madre gūla» se debe entender a través de su interpretación psicológica, según el concepto original de «la Gran Madre», quien, de acuerdo con la tradición oral, convivió con los seres humanos desde tiempos remotos. Por otra parte, Fares Khedr $^{23}$ interpreta que los narradores emplean la palabra «madre», «hermana» $\mathrm{o}$ «tía» para preceder a la mención a la gū $l a$ o el $g \bar{u} l$, de modo eufemístico, respetuoso y cercano, con el propósito de evitar sufrir un posible daño de este ser. En cuanto a su trato particular como «madre», podría derivar de las características físicas de la gūla dentro de la narrativa oral, que, como señala Rabadán (2003: II2), la describe con rasgos maternales muy marcados, puesto que está dotada de unos pechos exageradamente grandes. En otros cuentos árabes, como en los palestinos y los de la Cabilia, el intruso que consigue entrar en la morada de la gūla puede succionar el pecho que cuelga de una gūla, y de este modo convertirse en su hijo de crianza (Muhawi/Kanaana I989: 4I5-4I6) y estar a salvo. Mientras tanto en los CVN la gūla es un monstruo del tamaño de un burro y sus víctimas no tienen este medio específico de salvación, ya que emplea la leche de su pecho para elaborar una papilla con la que paralizar a sus víctimas, lo que le facilita el poder comérselas. Los cuentos 27-28, Abu Șarra, utilizan escenas bastante amedrentadoras para infundir el temor buscado, como esta en la que la $g \bar{u} l a$ encuentra a la niña escondida:

Le dijo [la gūla]:

¿Por dónde, cariño? ¿Por dóóónde te como? ¿Por dónde te como?

Le dijo:

Come de mis orejitas,

por no escuchar a mis hermanitas.

Y come de mis piernitas

por no correr como mis hermanitas.

23 En conversación privada no grabada. 
¿Y vivieron felices y comieron perdices?: la mujer casada en los cuentos populares...

\section{Conclusiones}

El estudio de los cuentos de esta región del desierto occidental egipcio sirve para conocer mejor estas poblaciones desconocidas en Occidente, pero también en el resto de Egipto, debido a que los cuentos populares son una fuente añadida de información sociocultural, etnográfica y sociolingüística que nos ayuda a conocer la realidad cotidiana, los intereses, los valores y las preocupaciones de este pueblo. Se puede comprobar cómo se retrata a la protagonista casada y su función dentro de la sociedad, que no es demasiado diferente de la tradición oral europea, pero que cuenta con especificidades sociales y etnográficas de esta región e insiste en ciertos elementos y atributos relacionados con la esposa, con la intención de evidenciar lo que se espera de ella.

Los CVN, al igual que el resto de los cuentos de la tradición universal, se interrelacionan con el pueblo que los narra. Por un lado, reflejan una realidad social, pero por otro también crean y autentifican un mundo social y moral determinado, en un flujo bidireccional. Aparte de su función como medio de entretenimiento, adquieren esta función pedagógica, para preservar las ideologías y los gustos más apreciados por el pueblo al que pertenecen, mientras que usan el poder sancionador de la comunidad para desechar aquellos relatos que no se adecúan a sus normas. Sus contenidos y su narración provocan una respuesta en su receptor y hacen perdurar un modelo de sociedad y valores concretos, que acostumbran a ser los de la sociedad tribal beduina: la hospitalidad, el coraje, la honestidad, el honor, la generosidad y la lealtad; junto con las normas tácitas de la tradición. Su transmisión se lleva a término, principalmente, a través de acciones y personajes; habida cuenta de que, en este género, los personajes son figuras arquetípicas, cada una de las cuales representa un modo de comportamiento.

Los CVN reflejan claramente la posición y los roles tradicionales árabes de hombres y mujeres establecidos por la comunidad y por lo tanto se muestran actitudes y comportamientos estereotipados de la mujer, fruto de una sociedad de estructura patriarcal; unos relatos donde la protagonista femenina desempeña un papel pasivo, en contraposición al papel activo del protagonista masculino. Esta pasividad generalizada de la mujer en los CVN definiría a los cuentos de este corpus como «cuentos de hombres», según la teoría del folklorista danés Bengt Holbek (I998: I6I). ${ }^{24}$ Ella es la encargada de la cocina, la que trabaja en el campo, cuida de los hijos y debe sometimiento al padre, al marido o al hermano.

Como particularidades más destacables de los CVN es necesario subrayar las siguientes:

En estos cuentos casi ninguna mujer escoge su matrimonio, y de entre ellas, un número considerable son raptadas.

En el inicio de los cuentos, donde se presenta el contexto familiar del héroe o la heroína, la figura de la madre se invisibiliza o está en un segundo plano con respecto a la del padre casi siempre.

La estabilidad de la mujer casada y su valor como esposa dependen de dar a luz hijos varones.

24 Según Holbek (I998), los cuentos maravillosos cuentan siempre con un héroe y una heroína. Si el papel activo lo lleva a cabo la heroína, se trataría de cuentos femeninos, y si lo realiza el héroe, pasarían a ser cuentos masculinos. Para más información sobre estos estudios, consúltese Oriol (20I7). 
Esta colección de cuentos populares descubre una tradición cuentística rica y antigua, cargada de componentes que ayudan a acercarnos a una cultura diferente; a un mundo fantástico poblado por los gūl, las gūla, los ŷinn y otros seres mágicos, pero también cargado de valores que se desean perpetuar, modelos a imitar y adquisición de compromisos para su receptor. En estos, se comprueba que la mujer casada de los CVN definitivamente no vivió feliz, como reza la conocida fórmula final. Es un personaje que sufre, vive en constante amenaza, y su principal enemigo es su propio esposo, que la prueba con dureza o la abandona, seguido de las mujeres de la familia de este.

Por último, cabe llamar la atención sobre el hecho de que los cuentos populares ocupaban ese papel de creadores de opinión pública e imaginarios sociales, al modo de los medios masivos de comunicación en la actualidad, y por los que han sido sustituidos en el Valle Nuevo: principalmente por la televisión. Esta ha eclipsado casi por completo la presencia de estos cuentos al ir falleciendo la generación que los contaba. Se han ido mudando los modelos de sus cuentos por aquellos que ofrece la pequeña pantalla de la televisión nacional egipcia, aunque cada vez empiezan a prevalecer más entre las nuevas generaciones del Valle Nuevo los contenidos que ofrecen las nuevas tecnologías, siguiendo la pauta existente en Occidente, aunque se lleve a término más paulatinamente. 
¿Y vivieron felices y comieron perdices?: la mujer casada en los cuentos populares...

\section{Referencias bibliográficas}

'ABD El-HAKīM, Shawqī (I985): Qāmūs al-kä’ināt al-jurāfìyya (Diccionario de seres míticos). Beyrut: Al-mu'asasa al- 'arabiyya li ad-dirāsa wa an-našr.

Austin, John (I982) [I962]: Cómo hacer cosas con palabras: Palabras y acciones (Genaro R. CARRIó y Eduardo A. RABOssi, trad.). Barcelona: Paidós.

Chevalier, Jean (I986): Diccionario de los símbolos (Manuel SiLvar y Arturo RodríGUEz, trad.). Barcelona: Herder.

HolbeK, Bengt (I998) [I989]: Interpretation of Fairytales. Helsinki: Suomalainen Tiedeakatemia.

IBRAHīm, Nabīla (I994): Ad-dirāsāt aš-ša 'biyya bayna an-nažarìyya wa-t-tațbīq (Los estudios populares, entre la teoría y la práctica). El Cairo: Al-maktaba al'akā dī miyya.

Muhawi, Ibrahim; Sharif KanaAna (I989): Speak, bird, speak again. Berheley y Los Angeles: Univesity of California Press.

NoIA, Camiño (20I5): «Contes de la femme convoitée et calomniée. À propos de la classification de contes-nouvelles». Estudis de Literatura Oral Popular/ Studies in Oral Folk Literature, núm. 4: 8I-94. DOI: http://dx.doi.org/IO.I7345/ elop20I58I-93

ORIOL, Carme (20I7): «Cuentos populares con protagonistas activas: la cara más desconocida de la tradición». En Marina SANFILIPPO; Helena GuZMÁN; Ana Isabel ZAMORANO (eds.): Mujeres de palabra: Género y narración oral en voz femenina. Madrid: UNED, p. I3-28.

RABADÁN, Montserrat (2003): La jrefiyye palestina: literatura, mujer y maravilla. El cuento maravilloso palestino de tradición oral. Estudio y textos. México: El Colegio de México.

SEARLE, John (I994) [I969]: Actos de habla. Ensayos de Filosofía y Lenguaje (L. Vlades Villanueva, trad). Barcelona: Planeta Agostini.

SEOANe, Celeste (2OI6a): «Cuentos populares y sociedad en los oasis del Valle Nuevo (Egipto)». Volumen I. Tesis doctoral dirigida por Nieves PARADELA y Camiño NoIA. Universidad Autónoma de Madrid. Disponible en línea en <https://repositorio.uam.es/handle/IO486/677699> [fecha de consulta: septiembre de 20I7].

— (20I6b): «Cuentos populares y sociedad en los oasis del Valle Nuevo (Egipto)». Volumen II (Corpus). Tesis doctoral dirigida por Nieves PARADELA y Camiño NoIA. Universidad Autónoma de Madrid. Disponible en línea en <https://repositorio.uam.es/handle/I0486/677699> [fecha de consulta: septiembre de 20I7].

EL-SHAMY, Hasan (2004): Types of the folktales in the Arab World: demographically oriented tale-type index. Bloomington: Indiana University Press.

El-SHAMY, Hasan; Jane GARRY (2005): Archetypes and motifs in folklore and literature: a handbook. New York/London: M. E. Sharpe.

UTHER, Hans-Jörg (2004): The Types of International Folktales. A classification and bibliography based on the system of Antti Aarne and Stith Thompson. 3 vols. Folklore Fellows' Communications, 284, 285, 286. Helsinki: Academia Scientiarum Fennica. 